\title{
THE CIRCULATING BLOOD VOLUME IN DIABETIC ACIDOSIS
}

By H. C. CHANG, ${ }^{1}$ GEORGE A. HARROP, JR., AND B. M. SCHAUB

(From the Medical Clinic of the Johns Hopkins Hospital and University, Baltimore)

(Received for publication November 21, 1927)

The clinical evidences of dehydration which are present during. severe acidosis in diabetes mellitus raises the question as to whether alterations may occur in the volume of the circulating blood. Such alterations, if present, would influence the apparent concentration of various blood constituents in acidosis and would be of pathological significance in several particulars. It seems likely that a marked reduction in blood volume, particularly plasma volume, would have some bearing, mechanically, on the occurrence of heart failure. It may also explain in part the occurrence, frequently observed, of renal irritation and insufficiency in diabetic coma. The terminal anuria, usually ascribed to lowering of the blood pressure, may also in part be due to a similar cause. Studies of the concentration of the plasma proteins, however, or of other blood constituents (1), have not certainly demonstrated alterations in the blood concentration, and we are not aware of previous attempts to measure the actual blood volume in this condition. We have therefore undertaken a study of the circulating blood volume in diabetic acidosis and the effect of treatment upon the blood volume. The technique for the determination of blood volume described in a previous communication is especially suitable for such a study and has been used here (2).

It has appeared to us that the character of the cases studied in an investigation such as this is of great importance and that in order to ascertain as far as possible the effects of diabetic acidosis alone, other possible complicating factors must be rigidly excluded. Circulatory disorders, arteriosclerosis, renal disease, inflammation, and fever may have important effects. The number of cases presented therefore is

1 Jacques Loeb Fellow in Medicine. 
small and includes only those of considerable severity in young individuals without any clinical evidences of renal or circulatory disease. The principal inciting cause of acidosis in each case chosen, so far as could be ascertained, was dietary. Cases with infection or fever have been avoided. Three of the cases had had evident symptoms of diabetes for less than six months, and had not until admission received insulin or sustained medical attention. The patient I. K. has been treated in this clinic for three years and has had known diabetes for about that period. The patient $\mathrm{E}$. had been admitted to the Johns Hopkins Hospital in coma on two previous occasions. He has had diabetes for two years. No attention had been paid by any of these patients, with the exception of E., to the fluid intake before admission.

The general plan of study has been as follows. The first estimation of the blood volume was made immediately upon admission of the patient to the ward. A portion of the preliminary blood sample drawn for a control estimation of the amount of carbon monoxide present in the blood was also utilized for measuring the blood sugar and plasma bicarbonate capacity as well as the oxygen capacity, red blood cell count and cell volume. The estimation was made at once before any treatment was instituted in order not to delay unduly the prompt administration of insulin and the employment of other measures. One or more subsequent measurements were then made during or after recovery as are indicated in table 1. The later determinations were delayed until complete recovery from acute acidosis was assured and the patients appeared to be in a state of equilibrium so far as diet and insulin dosage and freedom from glycosuria were concerned. The original degree of acidosis was always well marked, as is indicated, but it was deemed unwise to attempt studies on cases of frank coma presenting definite and urgent indications for emergency treatment.

The results obtained upon the five patients studied, together with the essential clinical data were similar in each of them, differing only in degree (table 1). It will be noted that recovery from acidosis was associated in each with a distinct rise in the blood volume, which in one case increased nearly 25 per cent. At the same time there was a diminution in the oxygen capacity of the blood, in the percentage cell 
volume, and, in general, a reduction in the erythrocyte count. It would seem that some relation exists between the degree of hyperpnea and the concentration of the blood, as well as the length of time during which acidosis had existed prior to treatment. The treatment consisted of the ordinary nursing measures together with the use of large doses of insulin, carbohydrates and fluids. In severe cases the fluids given amounted to as much as 8 or 10 per cent of the body weight per twenty-four hours. The fluids were given by mouth, by rectum, and subcutaneously, but in none of these patients were fluids administered intravenously. It would have been of interest to study the changes in blood volume resulting during the period of edema which is sometimes seen in poorly nourished individuals during recovery from severe diabetic toxemia, especially when the diet and particularly the carbohydrate ration is very low. None of the present cases, however, became edematous. Edema is in fact extremely rare in this clinic in the absence of manifest circulatory complications. We attribute this to the fact that care is taken to resume adequate balanced diets as early as possible, with sufficient insulin, and also to the fact that no sodium bicarbonate or other alkalies are used in the treatment.

The generalization is frequently made, and it is supported by a certain amount of evidence, that acidosis results in a loss of water from the body. In starvation this has been found to be associated with a depletion of base (3). The diuretic effect of ammonium chloride and of calcium chloride, to quote one example, is supposed to depend on the production of acidosis (4). It may be considered probable, therefore, that the blood shares in the dehydration of the other tissues during severe diabetic acidosis.

The results obtained in this study are somewhat at variance with those reported by other authors who have studied the blood volume after administration of insulin (5). The injection of insulin in animals is stated to produce a diminution of the blood volume. Its effect in human diabetes is certainly to relieve acidosis, and, as we have found, appreciably to increase the blood volume after recovery. In each of the cases reported in this paper large quantities of fluids have, however, also been given in the treatment of the acidosis and this may possibly counteract the tendency of insulin to reduce the blood 


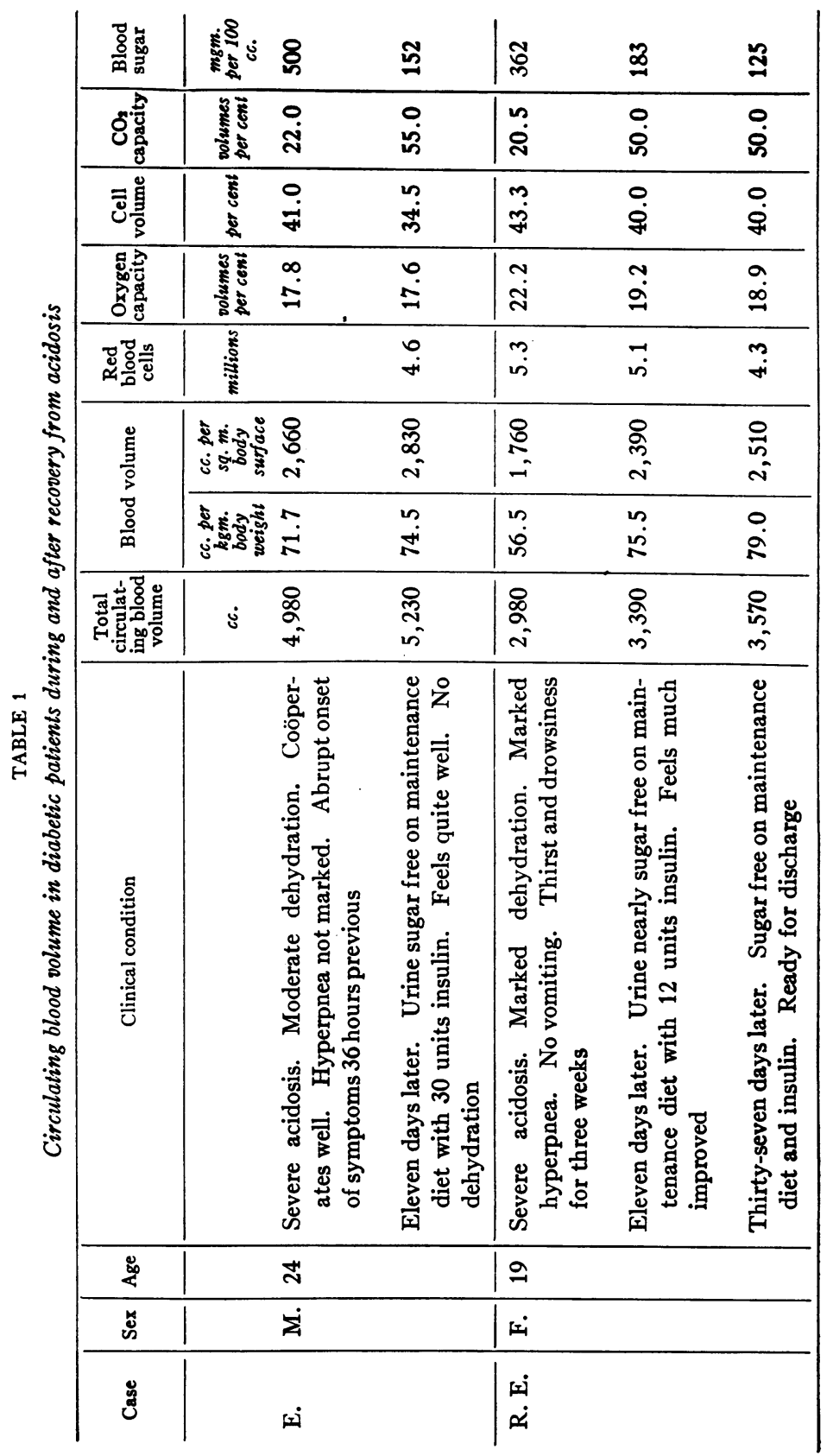


H. C. CHANG, G. A. HARROP, JR., AND B. M. SCHAUB

\begin{tabular}{|c|c|c|c|c|c|c|}
\hline స్త & $\underset{త}{\Phi}$ & $\beth$ & 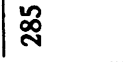 & ప゙ & శ్లి & శ్ర \\
\hline 官 & & 오 & $\mid \begin{array}{l}\infty \\
\ddot{\sim}\end{array}$ & $\vec{m}$ & $\mid \begin{array}{l}\stackrel{\sim}{\infty} \\
\sim\end{array}$ & $\stackrel{0}{\text { in }}$ \\
\hline 웅 & 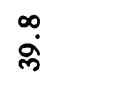 & 울 & $\mid \begin{array}{l}n \\
g \\
g\end{array}$ & $\stackrel{0}{j}$ & $\mid \begin{array}{l}0 \\
\text { o } \\
\text { q }\end{array}$ & $\stackrel{0}{9}$ \\
\hline$\ddot{a}$ & $\stackrel{\infty}{=}$ & $\hat{a}$ & $\mid \stackrel{\sim}{\grave{\lambda}}$ & $\stackrel{\sim}{\infty}$ & $\mid \tilde{i}$ & $\stackrel{\sim}{\infty}$ \\
\hline in & $\stackrel{a}{+}$ & $\stackrel{\bullet}{\dot{*}}$ & $\stackrel{0}{0}$ & $\stackrel{\text { n }}{+}$ & in & $\stackrel{\text { ri }}{*}$ \\
\hline$\stackrel{8}{\approx}$ & $\begin{array}{l}\text { ஜ } \\
\infty \\
\text {-1 }\end{array}$ & శ్ & 总 & $\stackrel{\tilde{a}}{a}$ & $\mid \begin{array}{l}\text { స్ } \\
\text { ஸे }\end{array}$ & $\begin{array}{l}8 \\
0 \\
-1\end{array}$ \\
\hline 잉 & 우 & $\stackrel{\circ}{i}$ & 17 & $\stackrel{\circ}{8}$ & $\mid \begin{array}{l}0 \\
\infty \\
0\end{array}$ & $\stackrel{0}{i}$ \\
\hline 芯 & $\begin{array}{l}8 \\
\text { i } \\
\text { i }\end{array}$ & $\begin{array}{l}\text { గ్ } \\
\text { ì }\end{array}$ & $\mid \begin{array}{l}8 \\
+ \\
i\end{array}$ & $\begin{array}{l}8 \\
\infty \\
\text { i }\end{array}$ & $\mid \frac{8}{8}$ & $\frac{8}{\pi}$ \\
\hline 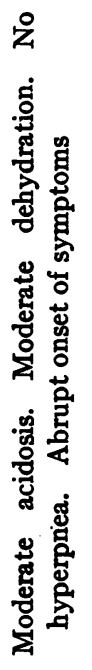 & 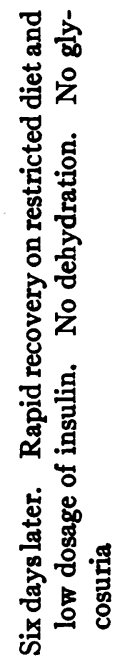 & 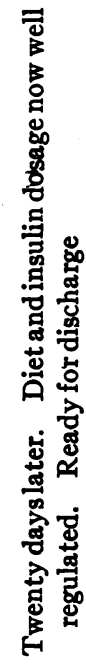 & 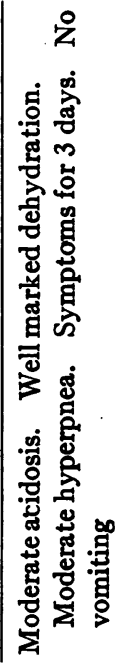 & 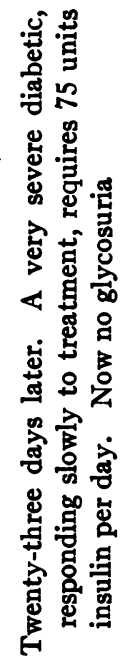 & 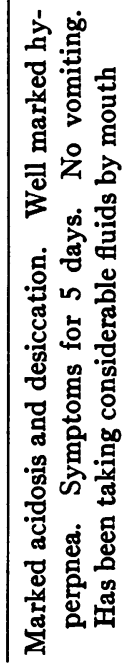 & 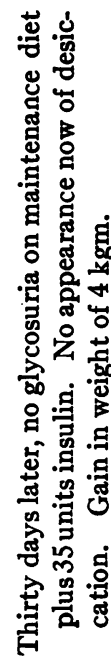 \\
\hline 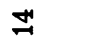 & & & 어 & & $\ddot{m}$ & \\
\hline Ixi & & & | & & $\Sigma$ & \\
\hline$\dot{\oplus}$ & & & $\dot{\mu}$ & & 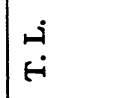 & \\
\hline
\end{tabular}


volume, if such is really its effect, in acidosis. There is other evidence, however, on the basis of changes in concentration of blood proteins which has been interpreted as indicating dilution of the blood after insulin in diabetic acidosis $(6,1)$. The effect of glycosuria alone in producing diuresis and dehydration has not in our experience resulted in reduction in the blood volume in diabetes.

Another factor in the production of dehydration in diabetic acidosis, and probably in the reduction in the circulating blood volume, is

TABLE 2

Changes in plasma and in cell volume during recovery from acidosis

\begin{tabular}{|c|c|c|c|c|}
\hline Case & $\mid$\begin{tabular}{c|} 
Total \\
circulat- \\
ing blood \\
volume
\end{tabular} & Plasma & Cells & Clinical condition \\
\hline \multirow{3}{*}{ E.. } & $c c$. & cc. & $c c$. & \\
\hline & 4,980 & 2,945 & 2,035 & During acidosis \\
\hline & 5,230 & 3,420 & 1,810 & After recovery from acidosis \\
\hline \multirow{3}{*}{ R. E.. } & 2,980 & 1,690 & 1,290 & During acidosis \\
\hline & 3,390 & 2,035 & 1,355 & \\
\hline & 3,570 & 2,145 & 1,425 & After recovery from acidosis \\
\hline \multirow{3}{*}{ D. B.. } & 2,250 & 1,350 & 900 & During acidosis \\
\hline & 2,360 & 1,415 & 945 & \\
\hline & 2,520 & 1,585 & 935 & After recovery from acidosis \\
\hline \multirow[t]{2}{*}{ I. K.. } & 2,460 & 1,245 & 1,215 & During acidosis \\
\hline & 2,890 & 1,620 & 1,270 & After recovery from acidosis \\
\hline \multirow[t]{2}{*}{ T. L.. } & 4,190 & 2,180 & 2,010 & During acidosis \\
\hline & 4,760 & 2,855 & 1,905 & After recovery from acidosis \\
\hline
\end{tabular}

the loss of water which must occur from the lungs during hyperpnea. On the basis of the moisture content of air saturated at $37^{\circ}$, the normal adult excretes from the lungs about 500 to $1000 \mathrm{cc}$. of water per twenty-four hours. During severe hyperpnea the respiratory exchange may be readily increased four to six fold with a proportionate increase in water loss through this channel. The total loss suffered in this manner, therefore, may readily amount to as much as five liters per twenty-four hours. There is every reason to suppose that in coma (cases of which we have not studied) this effect will be very 
marked and that the alteration of the circulating blood volume will in consequence be very great.

Table 2 gives in summary the plasma and cell volumes as calculated from hematocrit estimations. It will be noted, as was to have been expected, that the blood volume changes are chiefly due to changes in plasma volume, the volume of the cells being practically unchanged. The relationships are recorded graphically in the chart (fig. 1).

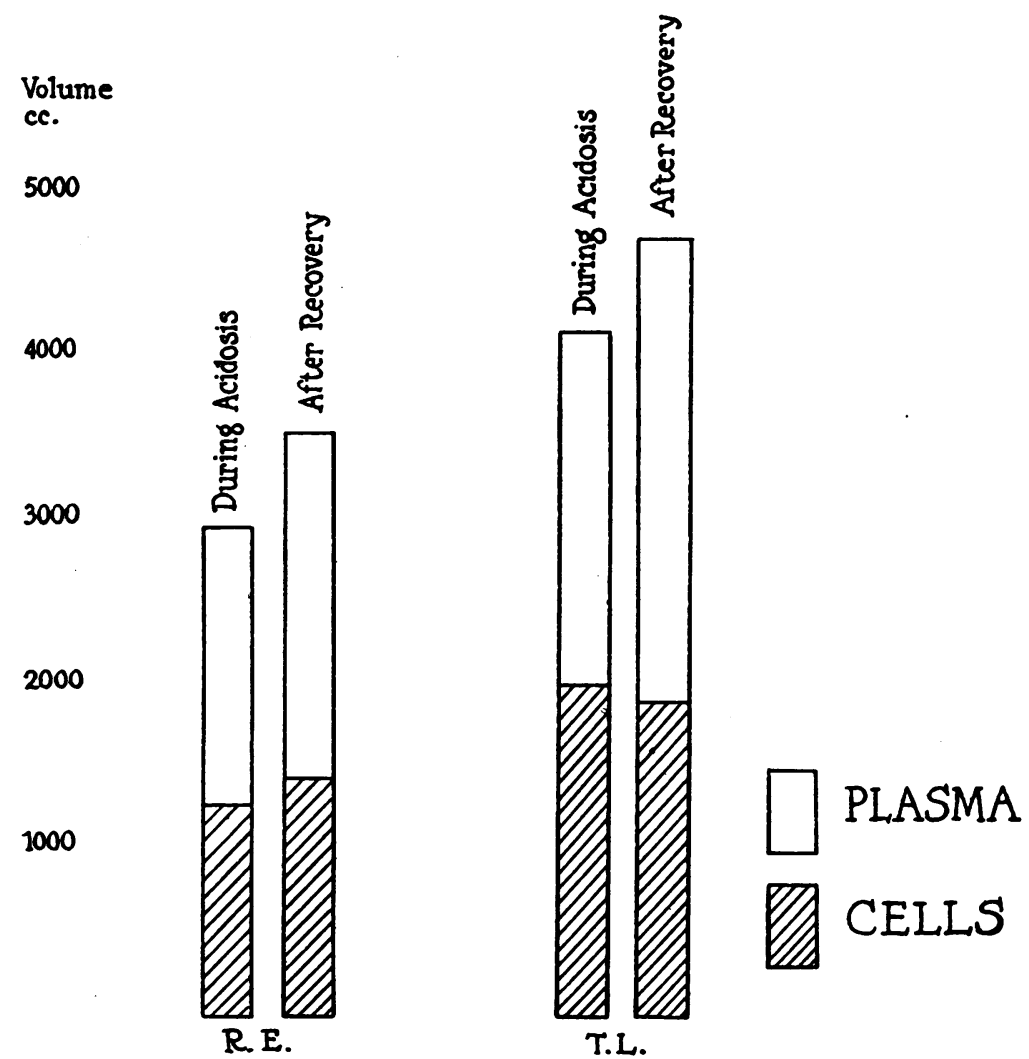

Fig. 1. The Changes in. the Relative Proporitions of Cell Volume and Plasma Volume during Diabetic Acidosis and after Recovery SUMMARY

During diabetic acidosis unaccompanied by any other known complicating factor, a well marked diminution in the circulating blood volume was found in five individuals. 
This diminution was accompanied by a corresponding increase in the oxygen capacity, the cell volume, and in the erythrocyte count of the blood.

The reduction in the blood volume was chiefly a reduction in plasma, the cell volume remaining intact.

After complete recovery from the acidosis the blood volume increased to within the normal limits, as estimated in the preceding paper.

\section{BIBLIOGRAPHY}

1. (a) Peters, J. P., Bulger, H. A., Eisenman, A. J., J. Clin. Invest., 1925, i, 451. The Plasma Proteins in Relation to Blood Hydration. II. In Diabetes Mellitus.

(b) Peters, J. P., Bulger, H. A., Eisenman, A. J., and Lee, Carter, J. Clin. Invest., 1925, ii, 167. Total Acid Base Equilibrium of Plasma in Health and Disease. VI. Studies of Diabetes.

2. Chang, H. C., and Harrop, G. A., Jr., J. Clin. Invest., 1928, v, 393. The Determination of the Circulating Blood Volume with Carbon Monoxide.

3. Gamble, J. L., Ross, G. S., and Tisdall, F. F., J. Biol. Chem., 1913, lvii, 633. The Metabolism of Fixed Base During Fasting.

4. Haldane, J. B. S., Lancet, 1921, i, 537. Experimental and Therapeutic Alterations of Human Tissue Alkalinity.

5. (a) Drabkin, D. L., and Edwards, D. J., Am. J. Physiol., 1924, lxx, 273. The Production of Anhydremia with Insulin.

(b) Haldane, J. B. S., Kay, H. D., and Smith, W., J. Physiol., 1924, lix, 193. The Effect of Insulin on Blood Volume.

(c) Drabkin, D. L. and Shelkret, H., Am. J. Physiol., 1927, lxxxiii, 141. Insulin Anhydremia. Importance of the Water-Reserve in a Physiological Crisis.

6. Widal, F., Abrami, P., Weill, A., and Laudat, Presse Med., 1924, xxxii, 565. L'Hydrémie au cours due diabète traité par l'insuline variations de l'indice réfractrométrique du sérum. 